\title{
BIOCHEMICAL ANALYSIS OF BLOOD OF NATIVE CATTLE IN THE HILLY AREA OF BANGLADESH
}

\author{
M. A. Mamun, M. M. Hassan, A. H. Shaikat, S. K. M. A. Islam, M. A. Hoque, M. Uddin ${ }^{1}$ and M. B. Hossain* \\ Department of Physiology, Biochemistry and Pharmacology, Chittagong Veterinary and Animal Sciences \\ University, Khulshi, Chittagong-4225, Bangladesh \\ ${ }^{1}$ Department of Anatomy and Histology, Chittagong Veterinary and Animal Sciences University, Khulshi, \\ Chittagong-4225, Bangladesh
}

\begin{abstract}
A yearlong study was carried out in indigenous cattle of five upazila namely Khagrachari Sadar, Laxmichari, Matiranga, Mahalchari and Dighinala in Khagrachari Hill District, Bangladesh for determination of statuses of various biochemical parameters. Apparently healthy cattle (100) were selected and blood samples were collected aseptically. Biochemical analysis of carbohydrates, proteins, fats, minerals, electrolytes and enzymes were performed by using automated biochemical analyzer (Humalizer $\left.{ }^{\mathbb{B}}-3000\right)$. The results showed that, the variations of parameters were not significant $(p>0.05)$ between male and female. Although there was a slight increase of calcium (Mean \pm SEM) $8.01 \pm 0.32 \mathrm{mg} / \mathrm{dl}$, glucose $69.21 \pm 2.31 \mathrm{mg} / \mathrm{dl}$, LDL $5.69 \pm 0.22 \mathrm{mg} / \mathrm{dl}$ and uric acid $3.85 \pm 0.34 \mathrm{mg} / \mathrm{dl}$ of female compared to $7.34 \pm 0.42,68.32 \pm 1.81,5.05 \pm 0.25$ and $3.37 \pm 0.27$ of the male. On the other hand, SGOT $(100.14 \pm 4.86 \mathrm{U} / \mathrm{L})$ was slightly higher in male compared to the female $(91.97 \pm 5.55)$. There was a slight variation in ALP $(218.81 \pm 29.12 \mathrm{U} / \mathrm{L})$ of growing cattle compared to the calf's $(293.57 \pm 42.78)$ and production cattle (300.88 \pm 27.24$)$, although the variation was not significant ( $>0.05)$.
\end{abstract}

Key words: Biochemical parameters, indigenous cattle, hilly area, age and sex

\section{INTRODUCTION}

Bangladesh is an agro-based country. Its economy is mostly depends on agriculture. Livestock plays an important role in nutrition directly through the consumption of animal products by livestock owners and their families; and indirectly through the sale of animals and animal products as a source of income (Aengwanich et al., 2009). Bangladesh stands 7th position in the world having 24.5 million cattle head (Bhuiyan et al., 2007). Biochemical determination of serum constituents can provide valuable informations as relating to nutrition, sex, age and physiological status of the animal (Osman and Al-Busadah, 2003). Biochemical analyses of blood serum are very useful to get insight in the metabolic and health status of animals. During diagnostic procedure, it is very useful to compare the values obtained from ill animals with normal values in healthy animals (Jezek et al., 2006). Biochemical parameters are responsible for various body functions and its deficiency result in impairment of functions induces structural and physiological abnormalities (Mcdowell, 1992). Cholesterol is not just mere waste product of metabolism but serves as one of the cells protective barriers to dehydration and infection (Jeremy, 2010). The impregnation of the membrane with cholesterol is also found in the reduction of fatty acids in the skin (Banerjee and Deshmare, 1990). Improvements of production traits become an important one for gaining of health and nutrition, which were vary not only species but also in age and sex. Livestock health is a limiting factor in production (Aengwanich et al., 2009). When practitioners fail to diagnose difficult cases through history and physical examinations, they turn to blood samples for a complete blood count and chemistry panel, hoping that these tests will help to identify the problem. The importance of hematobiochemical indices in animal husbandry is well acknowledged. Metabolic disturbance usually by inappropriate feeding without manifestation of clinical symptoms are important in animal husbandry and may cause insufficiently developed breeding cattle (Radostits et al., 2000). The changes in biochemical and hematological constituents are important indicators of the physiological or pathological state of the animal (Ahmed et al., 2009; Hassan et al., 2012). Blood examination is also performed for screening of general health (Peinado et al., 1999). It is well known that variables such as breed, stage of growth, age, reproduction status and stage of lactation have an influence on many blood parameters (Doornenbal et al., 1988).

\footnotetext{
*Corresponding e-mail address: mbhossaincvasu@yahoo.com
} 


\section{A. Mamun and others}

Determination of normal values for hematological and blood biochemical values are important for the clinical interpretation of laboratory data. These indices may vary depending on factors such as sex, age, weather, stress, season and physical exercise (Kaneko et al., 1997). Hence, the biochemical values during different physiological situations should be known for the diagnosis of various pathological and metabolic disorders, which can adversely affect the productive and reproductive performance of cows, resulting in great economic losses to dairy farmers (Dutta et al., 1988). This is a new research work on the biochemical indices of indigenous cattle in hilly area of Bangladesh. The aim of this study was to determine the biochemical parameters of male and female cattle and produce the clear picture of age and sex variations in hilly area.

\section{MATERIALS AND METHODS \\ Description of study area}

The study was carried out in five Upazila of Khagrachari Hill District such as Dighinala, Laxmichari, Matiranga, Mahalchari and Khagrachari Sadar where cattle were reared under free-range condition. 100 apparently healthy cattle were randomly selected from five Upazila in which 20 cattle from each Upazila.

\section{Sampling and sample collection}

According to age (1st group was 0-12 month, 2nd group 2-3 year and 3rd group above 3 year) and sex (male and female), the cattle were subdivided into three and two groups respectively, according to Benerjee, (1993). After proper investigation, the sampling was performed and approximately $8 \mathrm{ml}$ blood samples were collected from jugular vein aseptically. Collected blood samples were kept in vacutainer (without anticoagulant) for smooth coagulation. After coagulation, coagulated blood was centrifuged in 3000rpm for 15 minutes. Serum was transferred to the eppendorf tube by using micropipette. The obtained serum samples were stored in $-20^{\circ} \mathrm{C}$ at biochemical laboratory for biochemical test.

\section{Laboratory analysis of sample}

Proper aseptic measures were done at the time of serum analysis in the laboratory. Serum was placed in normal temperature approximately 30 minutes before the analysis. Serum samples were evaluated for glucose, total protein (TP), albumin, cholesterol, low density lipoprotein (LDL), alanine aminotransferase (ALT), aspartate aminotransferase (AST), alkaline phosphatase (ALP), magnesium (Mg), calcium (Ca), phosphorus (P), uric acid and creatinine by a automated biochemical analyzer (Humalizer $\left.{ }^{\circledR}-3000\right)$.

\section{Statistical analysis}

Obtained laboratory data was stored in Microsoft Excell-2007 and imported to the software STAT/IC-11.0 for analysis. Descriptive statistics analysis was done to measure the mean, SEM, 95\% confidence interval (CI) and P value of different parameters. The two sample paired t-test was done to compare the sex variation and $\mathrm{P}$ value $(\mathrm{p}<0.05)$ was considered for level of significance.

\section{RESULTS}

Different level of selected macromolecules and trace elements were found according to sex and age category in hilly area. Male has higher albumin, cholesterol, SGPT, SGOT, magnesium \& creatinine concentration in serum. Females have higher glucose, total protein, LDL, ALP, calcium, phosphorus \& uric acid concentration in serum. Enzymes such as SGPT and ALP were higher concentration in mature cattle (over 3 years of age). Growing cattle was containing higher albumin, SGOT, magnesium and phosphorus in serum. Calf was containing higher total protein, cholesterol, calcium and creatinine in serum. No significant variation $(\mathrm{p}>0.05)$ was found in overall selected macromolecules and trace elements in study hilly cattle.

\section{DISCUSSION}

The reported value of glucose indicates that female had higher serum glucose than male and calves contain more glucose than the growing and mature cattle that was agreed with the observations reported by Bondar et al. (1974). The decrease of glucose concentration in this study could be attributed to the nutritional status of the animals especially in the males was significantly lower than value obtained in the females (Payne, 1987).

The normal value of total protein indicates that female had higher serum total protein than male. This indicates that calves contain more total protein than the growing and mature cattle. This result indicated that decrease of TP level when age increased and which is in agreement with the result reported in Jersey x Red Kandhari cattle (Gaikwad et al., 2007) but another researcher recorded of contradictory results (Dubreuil and Lapierre, 1997). 
Table 1. Selected macromolecules and trace elements in serum based on sex

\begin{tabular}{|c|c|c|c|c|c|}
\hline \multicolumn{6}{|c|}{ Category } \\
\hline & \multicolumn{2}{|l|}{ Male $(\mathrm{N}=54)$} & \multicolumn{2}{|c|}{ Female $(\mathrm{N}=46)$} & \multirow[t]{2}{*}{$\mathrm{P}$ value } \\
\hline & Mean \pm SEM & $95 \% \mathrm{CI}$ & Mean \pm SEM & $95 \% \mathrm{CI}$ & \\
\hline \multicolumn{6}{|l|}{ Carbohydrate } \\
\hline Glucose (mg/dl) & $68.32 \pm 1.81$ & $64.70-71.94$ & $69.21 \pm 2.31$ & $64.56-73.86$ & 0.76 \\
\hline \multicolumn{6}{|l|}{ Proteins } \\
\hline Total proteins (g/dl) & $5.69 \pm 0.23$ & $5.22-6.16$ & $6.04 \pm 0.27$ & $5.49-6.58$ & 0.32 \\
\hline Albumin $(\mathrm{g} / \mathrm{dl})$ & $3.22 \pm 0.14$ & $2.94-3.51$ & $3.32 \pm 0.22$ & $2.88-3.75$ & 0.73 \\
\hline \multicolumn{6}{|l|}{ Lipids } \\
\hline Cholesterol (mg/dl) & $62.12 \pm 4.34$ & $53.41-70.84$ & $61.55 \pm 4.53$ & $52.41-70.69$ & 0.92 \\
\hline LDL (mg/dl) & $5.05 \pm 0.25$ & $4.56-5.57$ & $5.69 \pm 0.22$ & $5.23-6.13$ & 0.07 \\
\hline \multicolumn{6}{|l|}{ Enzymes } \\
\hline SGPT/ALT (U/L) & $31.92 \pm 2.77$ & $26.37-37.47$ & $30.92 \pm 2.58$ & $25.73-36.11$ & 0.79 \\
\hline SGOT/AST (U/L) & $100.14 \pm 4.86$ & $90.38-109.89$ & $91.97 \pm 5.55$ & $80.78-103.16$ & 0.27 \\
\hline $\operatorname{ALP}(\mathrm{U} / \mathrm{L})$ & $275.4 \pm 22.48$ & $230.31-320.48$ & $292.73 \pm 33.6$ & $225.06-360.1$ & 0.67 \\
\hline \multicolumn{6}{|l|}{ Trace elements } \\
\hline Magnesium (mg/dl) & $2.95 \pm 0.18$ & $2.60-3.30$ & $2.6 \pm 0.22$ & $2.16-3.04$ & 0.22 \\
\hline Calcium (mg/dl) & $7.34 \pm 0.42$ & $6.50-8.17$ & $8.01 \pm 0.32$ & $7.35-8.67$ & 0.21 \\
\hline Phosphorus (mg/dl) & $5.82 \pm 0.31$ & $5.20-6.45$ & $5.84 \pm 0.30$ & $5.23-6.45$ & 0.97 \\
\hline Uric acid (mg/dl) & $3.37 \pm 0.27$ & $2.81-3.93$ & $3.85 \pm 0.34$ & $3.17-4.53$ & 0.28 \\
\hline Creatinine $(\mathrm{mg} / \mathrm{dl})$ & $5.68 \pm 0.16$ & $5.36-5.99$ & $5.51 \pm 0.18$ & $5.14-5.87$ & 0.48 \\
\hline
\end{tabular}

The overall value of total protein was $5.85 \pm 0.18 \mathrm{~g} / \mathrm{dl}$ that was agreement with the observations reported by Gornal et al. (1949). On the other hand in albumin and cholesterol was found no significant variation $(\mathrm{p}>0.05)$. The serum LDL level was increasing at the increased of age.

There was no significant variation $(\mathrm{p}>0.05)$ observed in SGPT/ALT and SGOT/AST but was increasing at the increased of age and this finding is in agreement with the result in Jersey x Red Kandhari cattle (Gaikwad et al., 2007). The level of serum alkaline phosphatase may contain higher in female than the male. This result was indicated that the ALP was decreased at the increased of age and again it was increased at the mature stage (Gaikwad et al., 2007). The overall value of ALP was 283.37 $\pm 19.57 \mathrm{U} / \mathrm{L}$. This result was agreement with the observations reported by Pierre et al. (1976).

In magnesium and phosphorus, there was no significant variation $(\mathrm{p}>0.05)$ was observed. The results indicate that serum calcium may contain higher in female than the male. In calcium, the results indicate that this was decreasing at the increased of age and again it was increasing at the mature stage. There are non-significant alternative in the levels of calcium in male and female cattle. This result was agreement with the observations reported by Weissmann and Pileggi (1974). The results indicated that serum uric acid may contain higher in female than the male. The results was also indicated that the uric acid was increasing at the increased of age but the variation was not significant $((\mathrm{p}>0.05)$. Uric acid is a primary metabolic product of protein metabolism (Eggum et al., 1982). No significant variation $(\mathrm{p}>0.05)$ was observed in creatinine. 
Table 2. Selected macromolecules and trace elements in serum based on age

\begin{tabular}{|c|c|c|c|c|}
\hline \multirow[t]{2}{*}{ Parameter } & \multicolumn{4}{|l|}{ Category } \\
\hline & Age $\leq 1$ year & $2-3$ year & Age $>3$ year & $\mathrm{P}$ value \\
\hline & Mean \pm SEM & Mean \pm SEM & Mean \pm SEM & \\
\hline \multicolumn{5}{|l|}{ Carbohydrate } \\
\hline Glucose (mg/dl) & $71.17 \pm 2.56$ & $72.46 \pm 3.35$ & $66.69 \pm 1.93$ & 0.1706 \\
\hline \multicolumn{5}{|l|}{ Proteins } \\
\hline Total proteins $(\mathrm{g} / \mathrm{dl})$ & $6.14 \pm 0.36$ & $5.24 \pm 0.32$ & $5.94 \pm 0.25$ & 0.7002 \\
\hline Albumin (g/dl) & $3.2 \pm 0.23$ & $3.79 \pm 0.38$ & $3.12 \pm 0.15$ & 0.4766 \\
\hline \multicolumn{5}{|l|}{ Lipids } \\
\hline Cholesterol (mg/dl) & $84 \pm 7.39$ & $61.92 \pm 7.27$ & $63.25 \pm 3.94$ & 0.2593 \\
\hline $\operatorname{LDL}(\mathrm{mg} / \mathrm{dl})$ & $4.82 \pm 0.41$ & $5.33 \pm 0.32$ & $5.54 \pm 0.22$ & 0.6751 \\
\hline \multicolumn{5}{|l|}{ Enzymes } \\
\hline SGPT/ALT (U/L)) & $25.26 \pm 2.34$ & $26.89 \pm 2.93$ & $35.07 \pm 2.83$ & 0.7774 \\
\hline SGOT/AST (U/L) & $93.07 \pm 7.94$ & $105 \pm 8.58$ & $94.82 \pm 4.75$ & 0.7187 \\
\hline $\operatorname{ALP}(\mathrm{U} / \mathrm{L})$ & $293.57 \pm 42.78$ & $218.81 \pm 29.12$ & $300.88 \pm 27.24$ & \\
\hline \multicolumn{5}{|l|}{ Trace elements } \\
\hline Magnesium (mg/dl) & $2.81 \pm 0.22$ & $3.19 \pm 0.25$ & $2.56 \pm 0.20$ & 0.2397 \\
\hline Calcium (mg/dl) & $8.14 \pm 0.77$ & $6.8 \pm 0.56$ & $7.74 \pm 0.31$ & 0.4777 \\
\hline Phosphorus (mg/dl) & $5.68 \pm 0.55$ & $6.54 \pm 0.44$ & $5.66 \pm 0.27$ & 0.6438 \\
\hline Uric acid $(\mathrm{mg} / \mathrm{dl})$ & $3.24 \pm 0.53$ & $3.21 \pm 0.35$ & $3.83 \pm 0.29$ & 0.9189 \\
\hline Creatinine $(\mathrm{mg} / \mathrm{dl})$ & $5.76 \pm 0.31$ & $5.59 \pm 0.14$ & $5.48 \pm 0.30$ & 0.1956 \\
\hline
\end{tabular}

Total protein was $5.69 \mathrm{~g} / \mathrm{dl}$ and $6.04 \mathrm{~g} / \mathrm{dl}$ in male and female cattle respectively $(\mathrm{p}=0.32)$. Besides that males have a LDL value of $5.05 \mathrm{mg} / \mathrm{dl}$ whereas females have $5.69 \mathrm{mg} / \mathrm{dl}(\mathrm{p}=0.07)$ agreed by Gaikwad et al. (2007). In liver function test, low significance $(\mathrm{p}=0.27)$ of SGOT $(\mathrm{U} / \mathrm{L})$ was observed in between male $(100.14)$ and female (91.97) respectively that was agreed with the observation proposed by Andrei and Adela, (2004).

In electrolytes and minerals of male and female cattle were also estimated. Here magnesium was found as 2.95 $\mathrm{mg} / \mathrm{dl}$ in male whereas female has a value of $2.60 \mathrm{mg} / \mathrm{dl}(\mathrm{p}=0.22)$. Along with this, calcium level was found as $7.34 \mathrm{mg} / \mathrm{dl}$ and $8.01 \mathrm{mg} / \mathrm{dl}$ in male and female cattle respectively $(\mathrm{p}=0.21)$ was agreed with the Kaneko, (1989). A parameter of kidney function test namely creatinine was estimated and no significance is found in between male $(5.68 \mathrm{mg} / \mathrm{dl})$ with female $(5.51 \mathrm{mg} / \mathrm{dl})$ cattle $(\mathrm{p}=0.48)$ was agreed with Eggum et al. (1982). In this present study we found that different concentration of glucose $(\mathrm{mg} / \mathrm{dl})$, total protein $(\mathrm{g} / \mathrm{dl})$, albumin $(\mathrm{g} / \mathrm{dl})$, cholesterol (mg/dl), LDL ( mg/dl), SGPT (U/L), SGOT (U/L), ALP (U/L), magnesium (mg/dl), calcium (mg/dl), phosphorus $(\mathrm{mg} / \mathrm{dl})$, uric acid $(\mathrm{mg} / \mathrm{dl})$ and creatinine $(\mathrm{mg} / \mathrm{dl})$ in different groups of cattle. The variations of parameters were not significant $(\mathrm{p}>0.05)$ between male and female. Although there was a slight increase of calcium , glucose, LDL and uric acid of female compared to the male. On the other hand, SGOT was slightly higher in male compared to the female. There was a slight variation in ALP of growing cattle compared to the calf's and production cattle, although the variation was not significant $(\mathrm{p}>0.05)$. Most of the analyzed parameters were in normal range, which indicates that, the study populations are in healthy condition. Thus during diagnostic procedure it is very useful to compare the values obtained from ill animals with normal values of healthy animal (Jezek et al., 2006). 


\section{ACKNOWLEDGEMENT}

We are grateful to the Poultry Research and Training Center (PRTC) for financial support and thanks to the farmers of Khagrachari Hill District and Upazila Livestock Officers for their cooperation. We are also grateful to laboratory staffs of Physiology, Biochemistry and Pharmacology of Chittagong Veterinary and Animal Sciences University for their supports.

\section{REFERENCES}

1. Aengwanich W, Chantiratikul A and Pamok S (2009). Effect of seasonal variations on Hematological values andhealth monitor of cross breed beef cattle at slaughterhouse in Northestern part of Thailand. American-Eurasian Journal of Agricultural and Environmental Sciences 5 (5): 644- 648.

2. Ahmed I, Gohar A, Ahmed N and Ahmed M (2009). Haematological profile in cyclic and non- cyclic and Endometritic Cross breed Cattle. International of Journal of Agriculture and Biology 27: 83-91.

3. Andrei S and Adela P (2004). Profile of vitamine, enzime, hormone analize biochimice, Editura and ClujNapoca. Journal of ISBN 8: 434-555.

4. Banerjee K and Deshmare S (1990). Analysis of nonstructural polypeplids of Japanese encephalitis and West Nile virus. Indian Journal of Medical Microbiology 8: 17-22.

5. Benerjee GC (1993). A Text Book of Animal Husbandry. $5^{\text {th }}$ edition, Oxford and IBH Publishing co., New Delhi, India p: 450-451.

6. Bhuiyan AKFH, Shahjalal M, Islam MN, Rahman AKMA, Keown JF and Blake RW (2007). Characterization, conservation and improvement of red Chittagong cattle of Bangladesh. Proceeding of the USDA Project Review Workshop 1: 26-28.

7. Bondar RJL and Mead DC (1974). Evaluation of glucose phosphate dehydrogenase from leuconostoc mesteteroides in hexokinase method for determining in serum. Clinical Chemistry 20: 586-590.

8. Doornenbal H, Tong AK and Murray NL (1988). Reference values of blood parameters in beef cattle of different ages and stages of lactation. Canadian Journal of Veterinary Research 52: 99-105

9. Dubreuil P and Lapierre H (1997). Biochemistry references values for Quebec lactating dairy cows, nursing sows, growing pigs and calves. Canadian Journal of Veterinary Research 61: 235.

10. Dutta JC, Baruah RN, Dutta L and Talukdar SC (1988). Blood biochemical studies in anoestrous and normal cyclic cattle. Indian Veterinary Journal 65: 239-241.

11. Eggum BO, Thorbek L, Beames RM, Chuwa L, Log A and Henekel S (1982). Influence of diet and microbial activity in the digestive tract on digestibility and nitrogen and energy metabolism in rats and pigs. Journal of Polish Nutrition 48: 161-165

12. Gaikwad SM, Dhoble RL, Sawale AG, Mane PM and Dawane SC (2007). Osteomalacia in Holstein Friesian cow: a case report. Intas Polivet 8(2): 381

13. Gornal AG, Bardawill CJ and David MM (1949). Determination of serum protein by means of biuret reaction. Journal of Biological Chemistry 177: 751-766.

14. Hassan MM, Hoque MA, Islam SKMA, Khan SA, Hossain MB and Banu Q (2012). Efficiency of anthelmintics against parasitic infections and their treatment effect on production and blood indices in Black Bengal goats in Bangladesh. Turkish Journal of Veterinary and Animal Sciences 30 (4): 400-408.

15. Jeremy EK (2010). Cardiovascular efficiency Vs Nutritional Deficiency. International foundation for health and nutrition in San Diego. Journal of Veterinary Obstetrics 858: 2488-2533.

16. Jezek J, Klopcic M and Klinkon M (2006). Influence of age on biochemical parameters in calves. Bulletin of the Veterinary Research Institute in Pulawy 50: 211-214.

17. Kaneko JJ, Harvey JW and Bruss ML (1997). Clinical Biochemistry of Domestic Animals, Academic Press 5th Ed. San Diego.

18. Kaneko JJ (1989). Various biochemical evaluations of the domestic animals. In: Clinical Biochemistry of Domestic Animal. Academic Press 4th Ed. San Diego.

19. McDowell LR (1992). Minerals in animal and human nutrition. London, Academic pp. 265-293.

20. Osman TEA and AL-Busadah KA (2003). Normal concentrations of twenty serum Biochemical parameters of she-camels cows and Ewes in Saudi Arabia. Pakistan Journal of Biological Science 6 (14): 1253-1256.

21. Payne GM (1987). The metabolic profile Test, Oxford, England. Journal of Oxford Science 7: 33-38.

22. Peeler HT (1972). Biological availability of nutrients in feeds: availability of major mineral ions. Journal of Animal Science 35: 695.

23. Peinado VI, Celdran JF and Palomeque J (1999). Basic hematological values in some wild ruminants in captivity. Comparative Biochemistry and Physiology 124: 199-203. 
24. Pierre KJ, Tung KK and Nadj H (1976). A new enzymatic kinetic method for the determination of alpha amylase. Clinical Chemistry 22: 1219-1226.

25. Radostits OM, Gay CC, Blood DC and Hinchcliff KW (2000). Veterinary Medicine. $9^{\text {th }}$ Edn., W.B. Saunders Co. Ltd., London pp. 563-565.

26. Weissmann N and Pileggi VJ (1974). Inorganic ions. In: Clinical Chemistry, Principles and Techniques, 2nd Ed., Harper and Row, Hagerstown, MD. 